\title{
Pre-treatment of Yeast Production Wastewater and Hydrogen Production Based on MF-CSTR Process
}

\author{
Ding J.*, Jiang J. Y., Liu X. S. \\ School of Municipal and Environmental Engineering, Harbin Institute of Technology, Harbin, China \\ Email address: \\ dingjie123@hit.edu.cn (Ding J.), jiangjinyu_0313@126.com (Jiang J. Y.), 27286769@qq.com(Liu X.S.) \\ ${ }^{*}$ Corresponding author
}

\section{To cite this article:}

Ding J., Jiang J. Y. Liu X. S.. Pre-treatment of Yeast Production Wastewater and Hydrogen Production Based on MF-CSTR Process. International Journal of Environmental Monitoring and Analysis. Vol. 4, No. 5, 2016, pp. 131-139. doi: 10.11648/j.ijema.20160405.13

Received: August 17, 2016; Accepted: October 7, 2016; Published: October 17, 2016

\begin{abstract}
Wastewater produced during the yeast production has high COD concentration, chroma and turbidity and it is difficult to dissolve the water, which has constrained the development of yeast industry. This thesis researched the process of pretreatment of wastewater from yeast production wastewater. Membrane filtering was introduced to hold back the yeast existed in the wastewater. The filtered water was sent to produce hydrogen in anaerobic environment, while the residue was sent to extract protein. The filtering process utilized the PVDF membrane with an aperture of $0.2 \mu \mathrm{m}$ can hold back the yeast sufficiently. According to the transmembrane pressure, 10days worked as a period to clean the membrane at the aeration of $0.15 \mathrm{~m}^{3} \cdot \mathrm{h}^{-1}$. The cost as well as the profit is compared, which showed that for a yeast factory which had a daily wastewater production of $1000 \mathrm{~m}^{3}$, the profit could be as high as 1090 yuan $^{-1}{ }^{-1}$. Intermittent shake flask tests were conducted to study the difference of hydrogen production between direct anaerobic digestion and anaerobic digestion after filtration. When influent $\mathrm{pH}$ was 5.00, the hydrogen percentage of filtered group was $49.69 \%$, which exceeded the group without filtration by $20.34 \%$. The HRT and OLR were tested for CSTR to get the highest hydrogen production through anaerobic fermentation of the filtered yeast industry wastewater. Results showed that, when HRT was $8 \mathrm{~h}$ and OLR was $24 \mathrm{kgCOD} \cdot \mathrm{m}^{-3} \cdot \mathrm{d}^{-1}$, the system can get the highest biohydrogen production rate at $13.2 \mathrm{~L} \cdot \mathrm{d}^{-1}$. This test suggested that MF-CSTR pretreatment process can simultaneously treat yeast industry wastewater effectively and realize resource recovery from yeast protein and energy recovery and utilization from hydrogen, which provides the theoretical foundation for the treatment and resource utilization from yeast industry wastewater.
\end{abstract}

Keywords: Yeast Production Wastewater, Membrane Filtration, CSTR, Biohydrogen Production

\section{Introduction}

Energy is an important basis for human survival and development, and so far the energy structure is mainly based on coal, oil and natural gas which work as non-renewable resources. The continued use of finite fossil fuel resources has shifted thinking towards the future energy scenario of the world in the scarcity of fossil fuels [1]. In this regard, the alarm of accelerated global warming shifts the energy focus of the world to clean and renewable energies [2]. Therefore, developing renewable energy is inevitable. Hydrogen is a good energy carrier and is well considered as a substitute to the fossil fuels due to its high energy content and non-polluting nature during combustion [3]. The energy yield of hydrogen is about $122 \mathrm{~kJ} / \mathrm{g}$, which is 2.75 times greater than hydrocarbon fuels [4]. Hydrogen utilization is free of toxic gas formation as well as $\mathrm{CO}_{2}$ emission and the only product is water vapour. It is believed that a hydrogen-based economy would be less polluted than a fossil fuel based economy. Therefore more and more attention is paid for the development and utilization of the hydrogen energy.

Hydrogen can be produced by biological (dark fermentation, photofermenation, and biophotolysis) and non-biological (steam reforming) methods [5]. Currently, steam reforming of fossil fuels is the prevailing hydrogen production process; however, this process is considered as neither sustainable nor clean [6]. Compared with the method based on fossil fuels which consume plenty of energy as well as its high cost, biohydrogen production takes its unique advantages. In recent years, fermentative hydrogen production is given more attention than other biological production methods like photofermentation and biophotolysis due to its less-energy requirement and higher volumetric hydrogen production rate 
(HPR) [7]. Additionally, hydrogen can be produced from wide varieties of renewable organic wastes, which can reduce the operational cost and provide sustainable waste management

Yeast industry is an important and developing industry in China, and during its production large amounts of wastewaters are produced. About $60 \sim 130 \mathrm{t}$ wastewater are produced for $1 \mathrm{t}$ yeast as well as about 1.0 1.5t COD. The industrial production of yeast by fermentation that generally uses molasses as the raw materials includes operations and processes such as molasses preparation, fermentation, and separation and drying of yeast and produces a large quantity of high-strength liquid wastes. Mustafa [8] provided a detailed quantitative and qualitative identification and characterization of the wastewater sources from different processes of a baker's yeast industry which showed that the most polluted wastewater components of the facility were coming from rotary drum filter and evaporation process, while the highest pollution loads was identified as tank and equipment cleaning effluent due to very high flow rate from this source. The COD of high-concentration wastewater can reach as high as $80000 \mathrm{mg} \cdot \mathrm{L}^{-1}$, which contains about $0.5 \%$ dry matter including yeast protein, molasses, cellulose and other residual sugar that not entirely utilized during the fermentation, while the COD of the medium and low concentration waste water is about $1500 \sim 3000 \mathrm{mg} \cdot \mathrm{L}^{-1}$. The wastewater is a serious environmental pollutant due to its high organic content comprising mainly of reducing sugars, protein and volatile fatty acids. Conventional biological processes are effective in the removal of chemical oxygen demand (COD). However, the brown color remains in the biologically treated effluent due to the repolymerization of pigments [9]. The main colored compounds presented in the molasses fermentation wastewater are known as melanoidins which are responsible for the brown color, residual COD, and nitrogen in baker's yeast effluent that limits the recovery of wastewater [10]. A high chemical oxygen demand (COD), dark color, and high concentrations of total nitrogen and non-biodegradable organic pollutants are the characteristics of the wastewater produced by yeast industry which does harm to the fermentation [11]. Hence, biological treatment should be used in combination with other treatment technologies such as advanced oxidation processes, membrane processes, electrochemical processes, coagulation/flocculation, and adsorption. In fact, membranes technologies provide an important solution in environmental fields such as pollution reduction and water reuse, recycling valuable components from the waste streams [12]. In literature, some study has been found dealing with membrane treatment process for biologically treated baker's yeast wastewater [13-15].

It is highly imperative that appropriate experimental design is used to obtain the optimum process conditions. So in this thesis, the yeast production wastewater was dealt with MF-CSTR process, the yeast holding back by MF to realize recycling and the filtered water pouring into CSTR to produce hydrogen to realize energy utilization. The optimum conditions required to produce biohydrogen have been experimentally studied and different parameters are investigated to deal with the waster as well as realizing the sources and energy utilization.

\section{Materials and Methods}

\subsection{Wastewater and Seed Sludge}

The yeast industry wastewater which was used in this investigation was obtained from a local yeast production industry with its quality analysis showed in table 1 . And the characteristics of different batch of wastewater got from the factory had divergence.

Table 1. Characteristics of the yeast production wastewater.

\begin{tabular}{lll}
\hline Index & Unit & Yeast production wastewater \\
\hline $\mathrm{COD}$ & $\mathrm{mg} \cdot \mathrm{L}^{-1}$ & $5250 \sim 9240$ \\
$\mathrm{NH}_{4}{ }^{+}-\mathrm{N}$ & $\mathrm{mg} \cdot \mathrm{L}^{-1}$ & $341.5 \sim 495.4$ \\
$\mathrm{SS}$ & $\mathrm{m} \cdot \mathrm{L}^{-1}$ & $2120 \sim 3680$ \\
Total sugar & $\mathrm{mg} \cdot \mathrm{L}^{-1}$ & $365 \sim 684.8$ \\
protein & $\mathrm{mg} \cdot \mathrm{L}^{-1}$ & $1414 \sim 3396$ \\
$\mathrm{pH}$ & - & $6.34 \sim 8.29$ \\
chroma & Degree & $2200 \sim 3500$ \\
\hline
\end{tabular}

The seed sludge used in this study was obtained from a local municipal wastewater treatment plant. Prior to use, the sludge was first sieved through mesh with a diameter of $0.5 \mathrm{~mm}$ in order to remove waste materials that could cause pump failure. The ratio of mixed liquor volatile suspend solid (MLVSS) to mixed liquor suspend solid (MLSS) was 0.71 in the inoculated sludge. After inoculation, the sludge concentrations of each compartment were 17.9gMLVSS/L.

\subsection{Experimental Setup and Operation}

The membranes used in this essay were polyvinylidene fluoride (PVDF) hollow fiber membranes which were proven good chemical stability and high anti-contamination from
Tianjin Film Co., Ltd. The area of monolithic membrane is $1 \mathrm{~m}^{2}$. Due to that the size of the yeast is $1 \sim 5 \mu \mathrm{m} \times 5 \sim 30 \mu \mathrm{m}$, so the aperture of the membrane was selected $0.2 \mu \mathrm{m}$, with its fiber inner diameter of $0.7 \mathrm{~mm}$ and outer diameter of $1.1 \mathrm{~mm}$ as well.

Continuous culture was performed in a $30 \mathrm{~L}$ continuous stirred tank reactor (CSTR) with an effective volume of $5.8 \mathrm{~L}$ (Figure. 1). The reactor, operated in a continuous flow mode, was completely mixed by a variable speed stirred with a gear shift. Temperature was automatically kept at the level of $35 \pm 1{ }^{\circ} \mathrm{C}$ using a water bath which is connected with a temperature control device. The influent flow rate was controlled by a feed pump. The volume of biogas generated during the reactor operation was measured by a wet type gas meter connected with the reactor. 


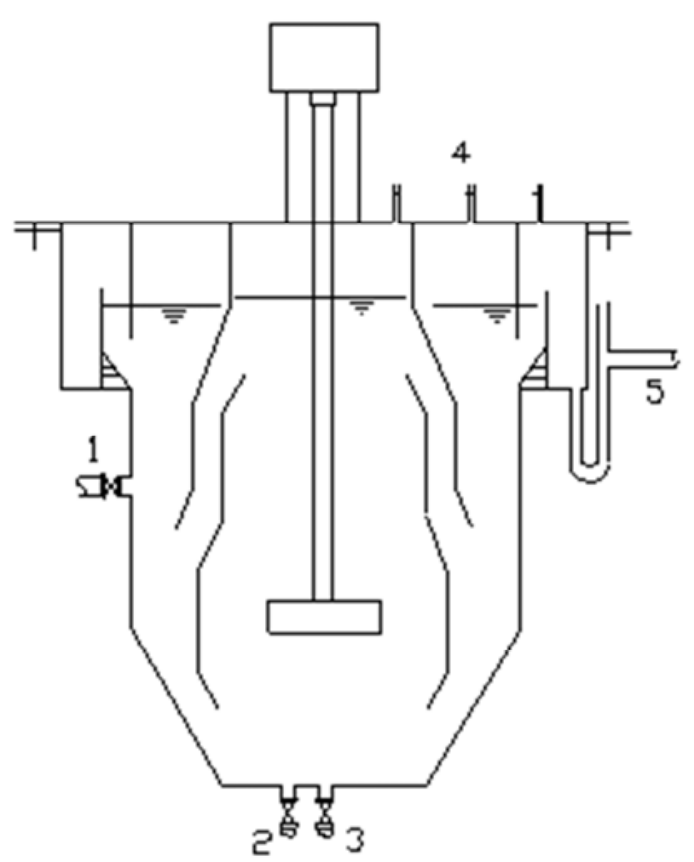

1- sampling port 2- sludge 3-influent 4-biogas outlet 5-effluent

Figure 1. Biogas and hydrogen yield in the CSTR system during fermentation at different HRT.

Batch experiments were conducted in glass bottles with a total working volume of $500 \mathrm{~mL}$ which includes $30 \mathrm{~mL}$ of yeast industry wastewater and $50 \mathrm{~mL}$ of seed sludge. No other organic materials were added to the reactors. The initial $\mathrm{pH}$ was adjusted as per the experimental requirement using $\mathrm{HCl}, \mathrm{NaOH}$ and deionized water $(5 \mathrm{~mL})$. Nitrogen was purged for $10 \mathrm{~min}$ in order to make an anaerobic condition and then incubated in an air shaker (HKZ-C, China) at agitation speed of $150 \mathrm{rpm}$ and the temperature $35 \pm 1^{\circ} \mathrm{C}$. The tests were conducted in triplicate for each concentration and all results were the mean value of replicate analyses.

\subsection{Analytical Methods}

Hydrogen production was calculated by measuring the gas components and the total volumes of the biogas produced. The contents of hydrogen in the biogas was analyzed using a gas chromatograph (Agilent 7890, USA ) equipped with a thermal conductivity detector (TCD) with its temperature of $200^{\circ} \mathrm{C}$, and the contents of methane were detected with the instrument equipped with a flame ionization detector (FID) with its temperature of $300^{\circ} \mathrm{C}$.

The concentrations of the volatile fatty acids (VFAs) and ethanol in the liquid phase were determined using another gas chromatograph (Agilent 7890, USA) equipped with a flame ionization detector (FID) with the temperature of $250^{\circ} \mathrm{C}$. The concentrations of the soluble protein in the liquor samples were measured by BCA method using bovine serum albumin as the standard solution, while the total sugar were determined by the phenol-sulfuric acid method [16] using glucose as the standard solution. Chemical oxygen demand (COD), $\mathrm{pH}$, MLVSS, MLSS were measured according to the procedures of Standard Methods.

\section{Results and Discussion}

\subsection{Filtration of Yeast Production Wastewater}

Membrane separation technology is natural or artificially synthesized membrane based on external energy or chemical potential difference as the driving force to realize grading, separation, purification and enrichment. It is shown from figure 2 that there were lots of black impurities and spherical yeast in the wastewater before filtration, while nothing was detected in the water after filtration, which indicated that the PVDF membrane selected could entrap the yeast cells effectively. In this way, the CSTR system was free of yeast which does good to biohydrogen production.
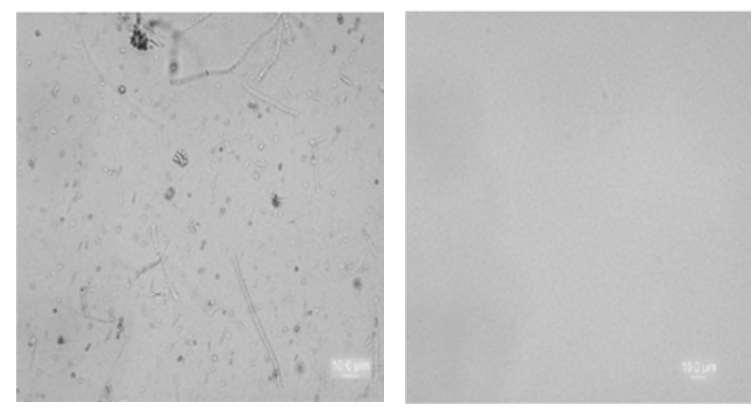

a) wastewater before filtration. b) wastewater after filtration

Figure 2. Microscopic photograph of wastewater before and after filtration.

The Suspended Solids (SS) concentration of yeast production wastewater is about $2000 \sim 4000 \mathrm{mg} \cdot \mathrm{L}^{-1}$, and after filtration the concentration of $\mathrm{SS}$ can be reduced to $200 \mathrm{mg} \cdot \mathrm{L}^{-1}$. Figure 3 which indicated SS concentration of wastewater before and after filtration showed that at the beginning of the filtration, the concentration of SS can be $500 \mathrm{mg} \cdot \mathrm{L}^{-1}$, and along with the process, the SS concentration declined. Finally, the removal efficiency of SS reached above $95 \%$. The interception of the suspension was limited to a certain degree due to the initial membrane pore size. The solution went through the surface of the membrane with longer filtration time, and the particle adsorbed on the surface of the membrane gradually thickened and compacted which leaded to the great decline in passing rate of the particle, and the interception was promoted which got a $95 \%$ removal efficiency of SS.

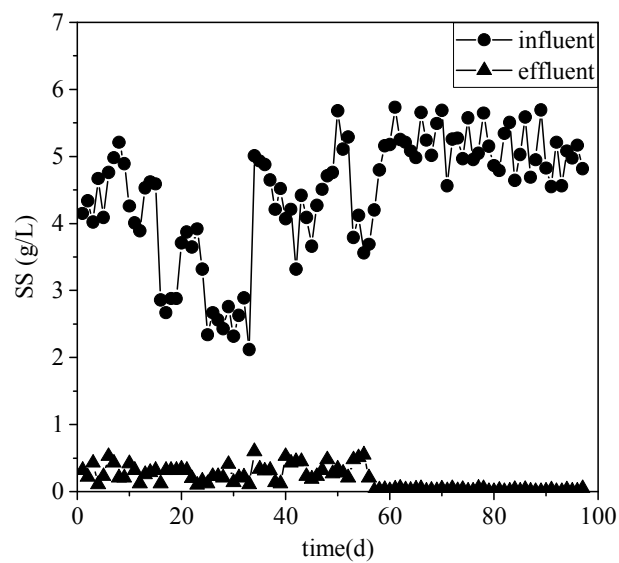

Figure 3. SS concentration of wastewater before and after filtration. 
The yeast production wastewater appeared to be dark brown due to the macromolecular caramel compound and melanoidin existing in the wastewater. The chrome showed in figure 4 indicated that the initial chroma of the raw water can reach 2 200 3 500degree, and after filtration, the chroma can only be 300 800degree. With the filtration going on, the membrane pore size is getting smaller, and removal efficiency of the chroma grow to $88 \%$ finally which indicated the high efficient of the chroma entrapped by the membrane. Thus the PVDF membrane used in this investigation can effectively hold back the matters that do harm to the anaerobic fermentation afterwards.

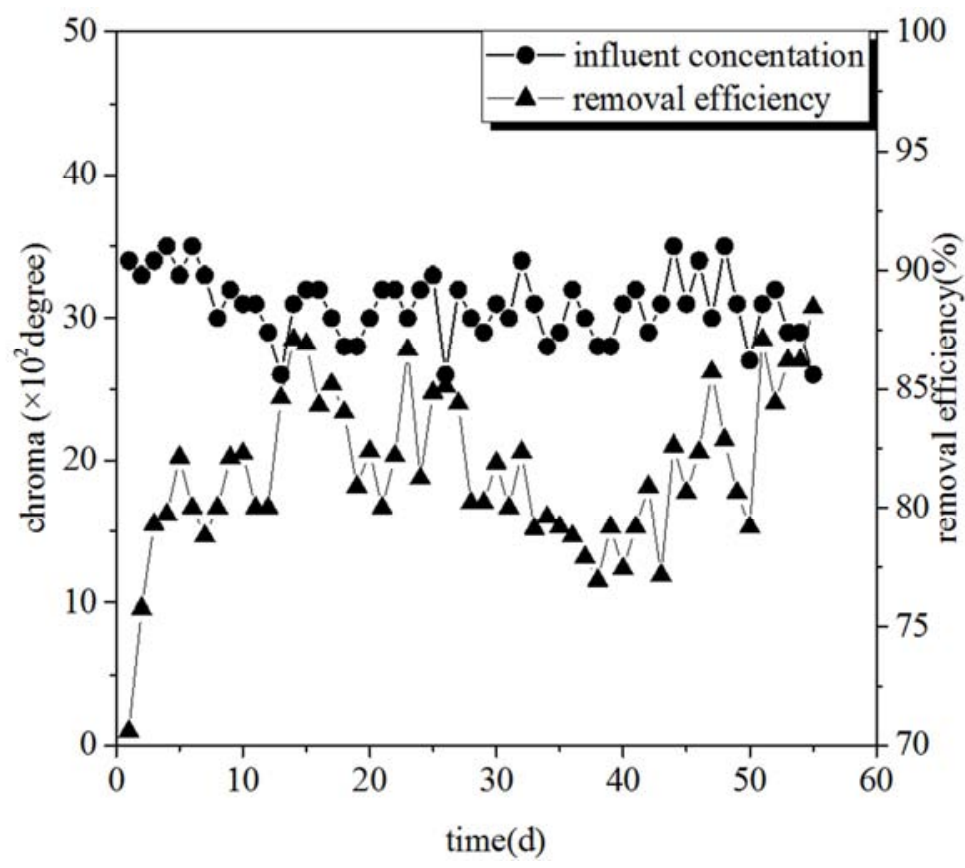

Figure 4. Chroma and the removal efficiency of the wastewater.

\subsection{Utilization of the Concentrate After Filtration}

The inflow of the wastewater was set as $30 \mathrm{~L} \cdot \mathrm{d}^{-1}$ and the accumulated concentration of SS were showed in figure 5 where the membrane worked under rated transmembrane pressure. It can be seen that 10days works as a period, and the accumulated SS concentration can reach $20 \mathrm{~g} \cdot \mathrm{L}^{-1}$, and by this time the sludge in the filtration reactor can submerge about $75 \%$ area of the membrane which seriously harm the filtration process, so every 10days, the reactor are clear and the membrane cleaned with backwash and chemical detergent.

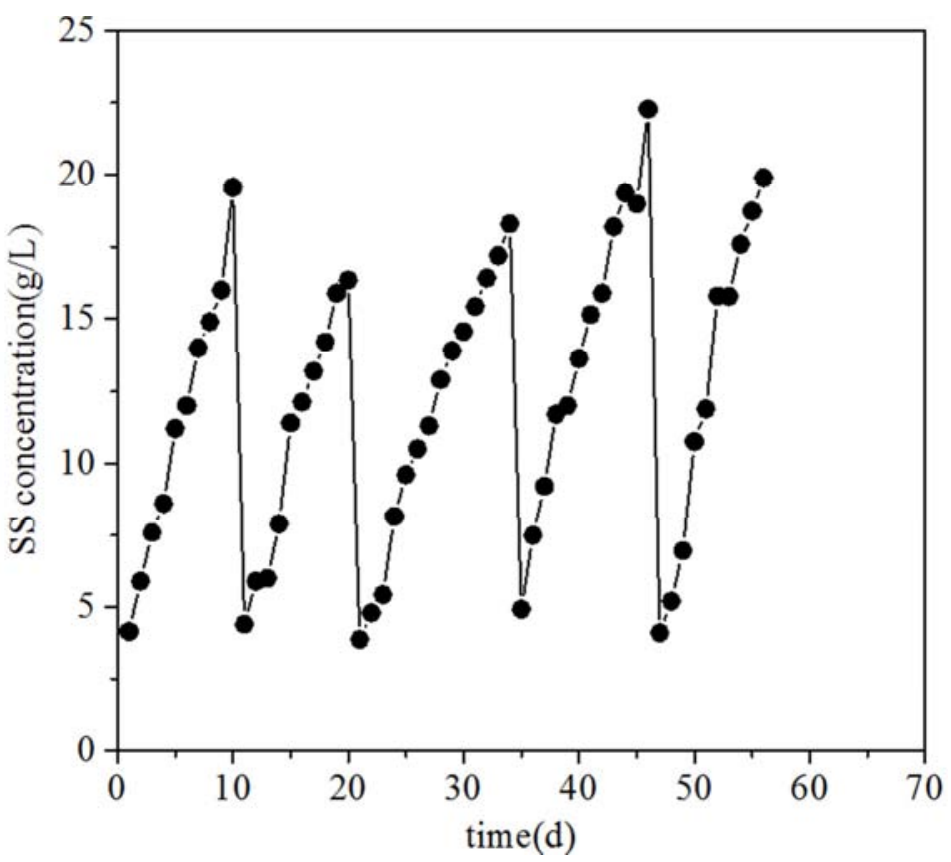

Figure 5. Chroma and the removal efficiency of the wastewater. 
After the composition of the SS determined which showed in figure $6,42.16 \%$ of protein was included which mean that the protein got every period could reach $8.5 \mathrm{~g} \cdot \mathrm{L}^{-1}$. Besides of the calcium and magnesium included in the concentrate, it can be made into fertilizer for sale. The concentrate got from filtration was dealt with concentrating-spray-granulating process to make superior organic and inorganic compound fertilizer. And the followings are the economic accounting for utilizing the concentrate.

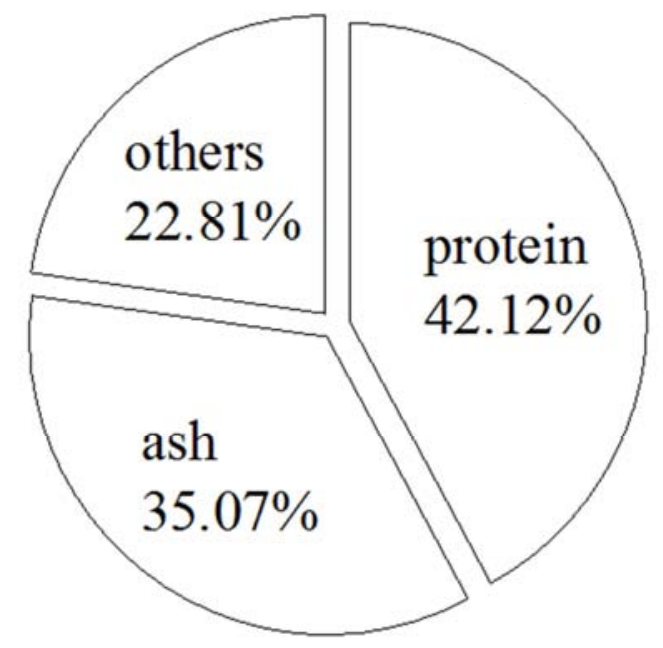

Figure 6. Composition of the SS in the filtration reactor.

(1) Membrane depreciation expense: the membrane used in the experiment was flat-plat membrane whose cost could be measured as 0.54 yuan $/ \mathrm{t}$ water.

(2) Electric charge: the motor capacity designed was $99.7 \mathrm{kw}$ while the actual operating capacity was $56.5 \mathrm{kw}$. And the electric charge was $56.5 \times 24 \times 0.7 \times 0.06 \div 1000=0.57 \mathrm{yuan} / \mathrm{t}$ water, where 0.70 was the power coefficient.

(3) Chemical cost: cost of the chemical agent used for the cleaning of membrane was about $1.25 y u a n / t$ water.

(4) Labor cost: there were 5 persons including 2 manager and laboratory staffs with $3000 y u a n /$ person/month, and 3 operators with $2500 y u a n /$ person/ month. The cost was about $(3000 \times 2+2500 \times 3) \div 1000 \div 30=0.45$ yuan $/ \mathrm{t}$ water.

The total cost referred above was $0.54+0.57+1.25+0.45=2.81$ yuan $/ \mathrm{t}$ water.

The concentrate got after filtration, $13 \mathrm{~kg}$ sludge was got from $1 \mathrm{~m}^{3}$ wastewater. The market price was $0.5 \mathrm{yuan} / \mathrm{kg}$, while $0.3 y u a n / \mathrm{kg}$ was calculated in this experiment. So $1.09 y u a n$ economic benefit could be got by dealing with $1 \mathrm{t}$ water. A yeast factory which has a daily wastewater production of $1000 \mathrm{~m}^{3}$, the profit can be as high as 1090 yuan $\cdot \mathrm{d}^{-1}$, which highlights the economic feasibility of extraction of protein from wastewater.

\subsection{Biohydrogen Production Property of Yeast Wastewater Before and After Filtration}

Batch anaerobic formation tests of the yeast industry wastewater were conducted to compare the biohydrogen production under different conditions. The different conditions for the fermentation were showed in table 2. $\mathrm{C} 1 \sim \mathrm{C} 3$ was conducted under different initial $\mathrm{pH}$ with raw yeast industry wastewater while P1 $\sim$ P3 was operated with outlet water after filtration.

Table 2. Different fermentation conditions of the batch array.

\begin{tabular}{lll}
\hline No. & Initial pH & Substrate \\
\hline C1 & 8.00 & Raw water \\
C2 & 6.00 & Raw water \\
C3 & 5.00 & Raw water \\
P1 & 8.00 & Raw water after MF \\
P2 & 6.00 & Raw water after MF \\
P3 & 5.00 & Raw water after MF \\
\hline
\end{tabular}

The yeast cells in the yeast production wastewater would compete to live to inhibit the biohydrogen production process, so here in the experiment, the influence of the yeast for biohydrogen production was tested by comparing the fermentation before and after filtration. Figure 7 showed that when initial $\mathrm{pH}$ was set at 5.00 , the wastewater after filtration would get the highest hydrogen production $(155.69 \mathrm{~mL})$, and the percentage of hydrogen reach $32.9 \%$, while the fermentation of raw water got lower hydrogen production, which indicated that the MF process does good to the following fermentation.

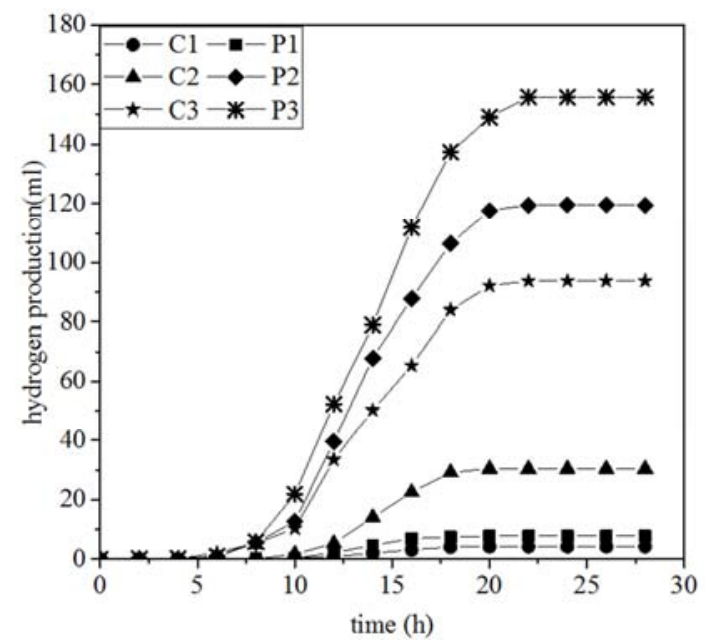

Figure 7. Accumulated hydrogen production at different $\mathrm{pH}$.

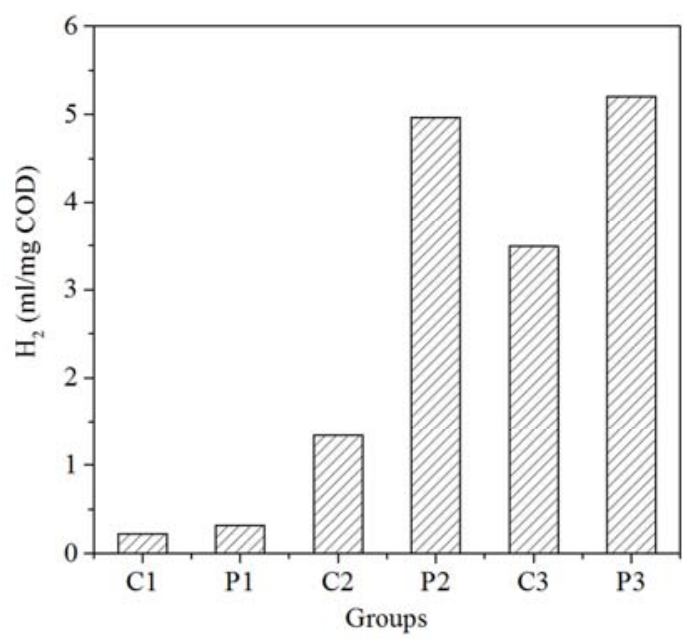

Figure 8. Ratio of hydrogen production rate under different $\mathrm{pH}$. 
Figure 8 showed the ratio of hydrogen production, and it showed that when $\mathrm{pH}$ was 5.00 , the wastewater after filtration got the most at $5.20 \mathrm{ml} \cdot \mathrm{mg}^{-1} \mathrm{COD}$ while the raw water only got $3.49 \mathrm{ml} \cdot \mathrm{mg}^{-1}$ COD.

Thus the wastewater after filtration got higher hydrogen production than the raw water, which means that MF could do good to the following fermentation.

\subsection{Startup of CSTR}

Table 3 which showed the characteristic of the yeast production wastewater after filtration that, the characteristics of the different batch of waste water has a little difference, so at the beginning of the startup of the reactor, the parameter should be kept stable to some extent.

Table 3. Characteristics of the wastewater after filtration.

\begin{tabular}{lll}
\hline Index & Unit & Yeast wastewater after filtration \\
\hline $\mathrm{pH}$ & - & $7.00 \sim 8.00$ \\
$\mathrm{COD}$ & $\mathrm{mg} \cdot \mathrm{L}^{-1}$ & $5000 \sim 7000$ \\
$\mathrm{NH}_{4}{ }^{+}-\mathrm{N}$ & $\mathrm{mg} \cdot \mathrm{L}^{-1}$ & $340 \sim 490$ \\
$\mathrm{SS}$ & $\mathrm{mg} \cdot \mathrm{L}^{-1}$ & $220 \sim 312$ \\
Total sugar & $\mathrm{mg} \cdot \mathrm{L}^{-1}$ & $351 \sim 662$ \\
protein & $\mathrm{mg} \cdot \mathrm{L}^{-1}$ & $2000 \sim 3600$ \\
\hline
\end{tabular}

At the beginning of the experiment, COD concentration was kept at $6000 \mathrm{mg} \cdot \mathrm{L}^{-1}$ of influent into CSTR, while COD:N:P was 255 500:5:1. The temperature was controlled around $35 \pm 1{ }^{\circ} \mathrm{C}$, the $\mathrm{pH}$ of the yeast waste water after filtration was $7.1 \sim 8.1$. Different kinds of parameters were tested to judge the performance of CSTR system.

The concentration and removal efficiency of COD is one of the indexes to show the performance of the reactor. It is shown from figure 9 which showed the COD in CSTR during the startup of the reactor, when the reaction starts $1 d$, since there was oxygen in the reactor, facultative bacteria still kept relatively high metabolic activity and the removal efficiency of COD got up to $37.27 \%$. Two days after operation, due to the system environment became into dramatic changes from the aerobic to anaerobic environment, facultative anaerobes activity decreased, and some floras even got to die, the amount of sludge reduced, the microorganism activity declined as well, so that COD removal rate decreased to $13.22 \%$. When it comes to the $10^{\text {th }}$ day, the removal efficiency of COD was around $27 \%$ and maintained fluctuations. This is because that the microflora in CSTR gradually adapted to the environment and anaerobic microorganisms breed and microbial activity has gradually restored. The reactor operating conditions stabilized and the efficiency kept stable which may indicate the startup of CSTR at about 10days.

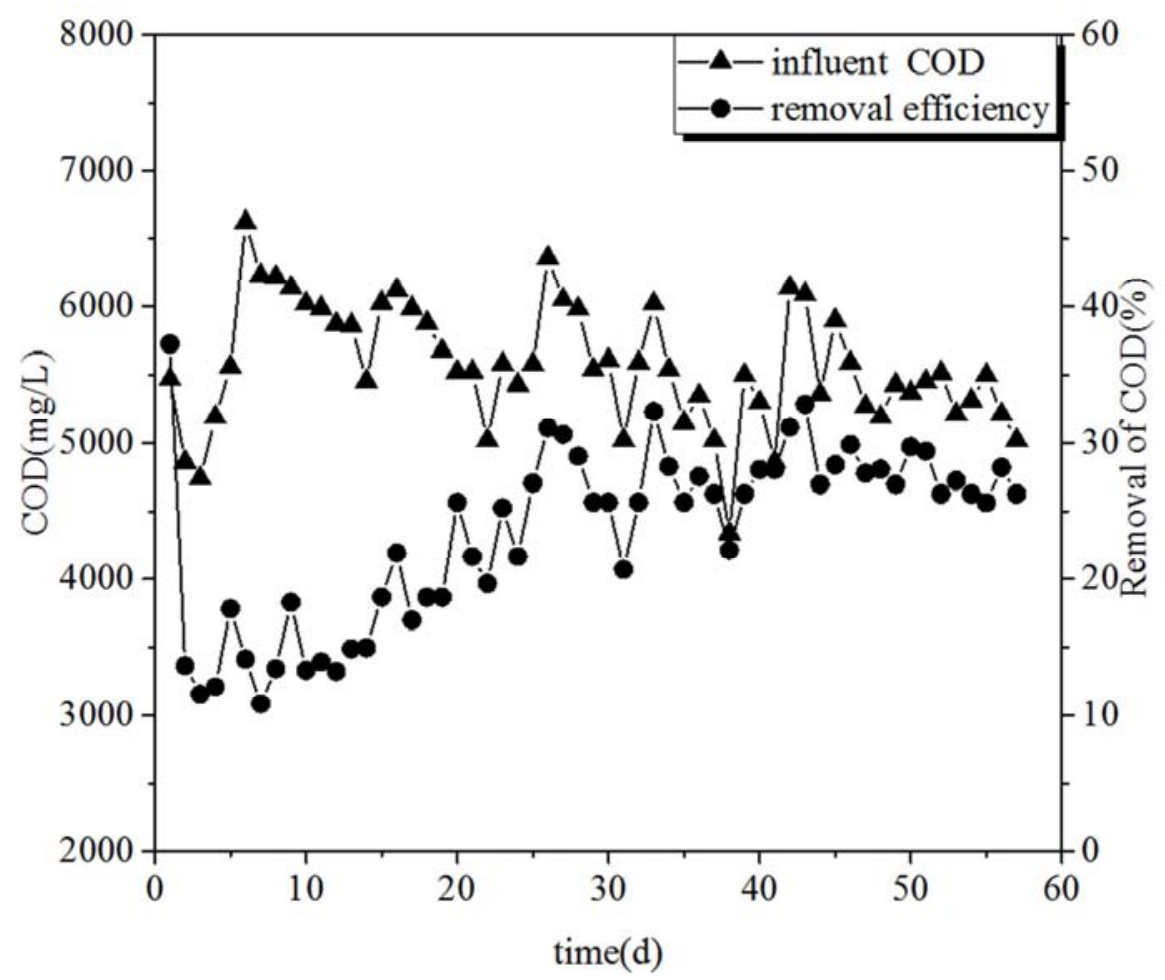

Figure 9. Removal efficiency of COD during the startup of the reactor.

The $\mathrm{pH}$ is an important factor for anaerobic hydrogen production. Figure 10 showed the changes of $\mathrm{pH}$ during the startup of the reactor. At the beginning of the operation, because of the high $\mathrm{pH}$ of the influent, the effluent was a little high, and along with the operation of the reactor, microflora gradually adapted to the environment and the liquid by-products during the fermentation accumulated which lead to the decline of $\mathrm{pH}$. When the reactor run after about 14days, the
$\mathrm{pH}$ dropped to 4.51 and kept stable to some extent. The changes of $\mathrm{pH}$ affected not only the anaerobic hydrogen production ability, but also the microbial community and fermentation types. So $\mathrm{pH}$ is most important parameter for CSTR system. When the influent kept at about 7.00 while the effluent kept around 4.50, the startup of the reactor was successful. 


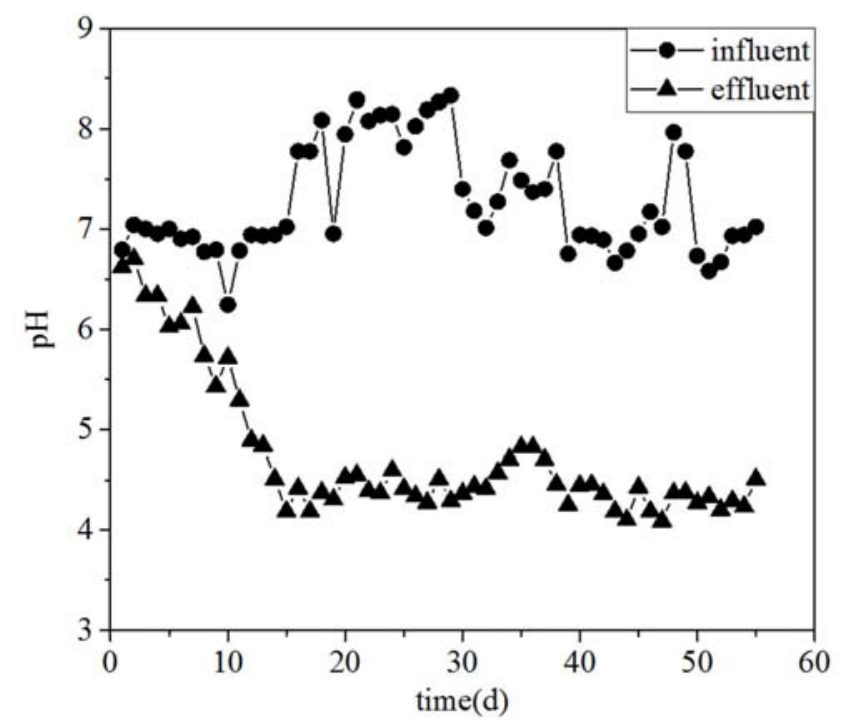

Figure 10. Changes of pH during the startup of the reactor.

Production of biogas during the startup the reactor is a most important index to indicate the performance of the reactor. Figure 11 showed the changes of biogas and hydrogen production and composition during the operation. The biogas produced gradually grew to about $20 \mathrm{~L} \cdot \mathrm{d}^{-1}$ until the $6^{\text {th }}$ day. And hydrogen began to exist from the $3^{\text {nd }}$ day, and gradually increased along with the fermentation because that the hydrogenogens grew to adapt the environment, and the activity of them kept higher which lead to the increase of the percentage of hydrogen among the biogas produced. The reactor produced biogas stably at about the $6^{\text {th }}$ day, and the hydrogen production gradually increased, when it comes to the $12^{\text {th }}$ day, the yield of hydrogen got stable at about $8 \mathrm{~L} / \mathrm{d}$, with its percentage of $35 \%$.

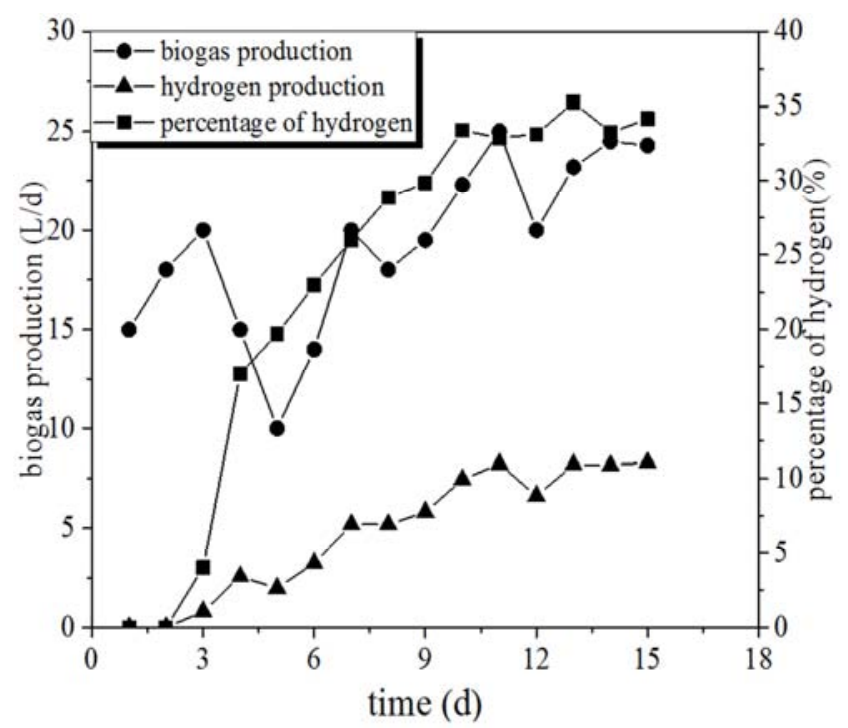

Figure 11. Biogas production during the startup of the reactor.

By measuring different kind of parameters of the reactor during the startup, analysis showed that the reactor run around $15 \mathrm{~d}$ has been launched successfully, and maintained at a relatively stable operation. When influent COD concentration was maintained at $6000 \mathrm{mg} \cdot \mathrm{L}^{-1}, \mathrm{COD}$ removal efficiency achieved $27 \%$, and the effluent $\mathrm{pH}$ value around 4.5 . The hydrogen production rate can achieve $8 \mathrm{~L} \cdot \mathrm{d}^{-1}$ at the same time. And the reactor was successfully started.

\subsection{Optimization of CSTR}

\subsubsection{Influence of HRT for Fermentation}

HRT is an important parameter for dark fermentation processes. In a CSTR system, short HRTs are used to wash out the slow growing methanogens and select for the acid producing bacteria, while too high dilution rate corresponding to long HRTs could lead to inefficient hydrolysis of organic wastes. Nevertheless, bacterial cells washout under short hydraulic retention time (HRT) is a major problem associated with the CSTR, which leads to the process instability and inefficient hydrogen production [17]. So to have a reasonable HRT is important for CSTR operation.

The $\mathrm{H}_{2}$ yield has generally been considered as an important index to evaluate the anaerobic fermentation. As shown in Figure 12, the changes of HRT had a great impact on the CSTR system. Biogas production increased from $9.8 \mathrm{~L} \cdot \mathrm{d}^{-1}$ to $19.7 \mathrm{~L} \cdot \mathrm{d}^{-1}$ belonged with the increasing of HRT from $2 \mathrm{~h}$ to $6 \mathrm{~h}$. While the HRT was adjusted from $6 \mathrm{~h}$ to $12 \mathrm{~h}$, the biogas production decreased to $11.9 \mathrm{~L} \cdot \mathrm{d}^{-1}$. At the same time, highest $\mathrm{H}_{2}$ production of $9.8 \mathrm{~L} \cdot \mathrm{d}^{-1}$ was observed in CSTR at HRT $8 \mathrm{~h}$. During the fermentation, there was no methane detected.

It was evident that typical anaerobic mixed cultures could not produce $\mathrm{H}_{2}$ as it was an intermediate for methane formation, and was rapidly consumed by methane-producing bacteria [18]. The most effective way to enhance $\mathrm{H}_{2}$ yield from the anaerobic culture is to restrict or terminate the methanogenesis process by allowing $\mathrm{H}_{2}$ to become an end-product in the metabolic flow. It could conclude that the reactor operated with shorter HRT suppressed the activity of methanogenic and the methanogenic population in the anaerobic inoculum might also be inhibited.

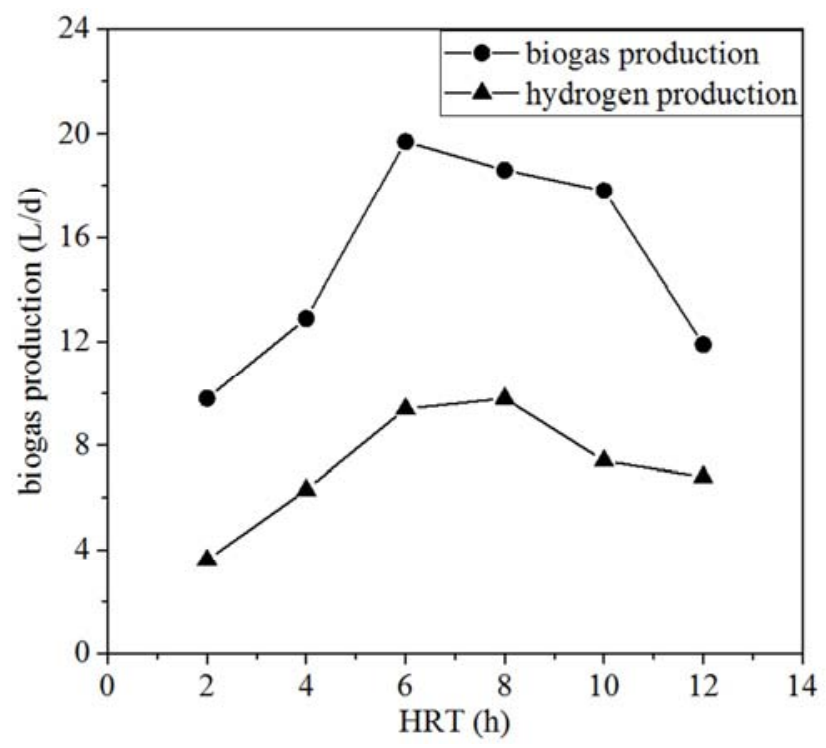

Figure 12. Biogas and hydrogen yield in the CSTR system during fermentation at different HRT.

During this experiment, at a relatively short time of HRT, 
anaerobic degradation of organic substrate can be relatively effective. But HRT can't be too short, when it is less than $4 \mathrm{~h}$, the sludge would be rushed out of the reactor, the substrate doesn't have sufficient time for hydrolysis acidification, and the hydrogen content of the hydrogen production rate dropped significantly respectively. So HRT between $6 \mathrm{~h}$ to $10 \mathrm{~h}$ does well to hydrogen production during the fermentation of the CSTR system.

The removal efficiency of COD is an important index to evaluate the reactor performance. Figure 13 showed that the removal efficiency of COD increased with HRT. When HRT increased to $10 \mathrm{~h}$, the COD removal efficiency reached $30.5 \%$, while total sugar degradation rate reached its maximum $93.6 \%$ at the HRT $8 \mathrm{~h}$. Furthermore HRT is small, less than the bacterial generation reproductive cycle, a large number of micro-organisms will be rushed out of the reactor, resulting in low fermentation efficiency, which also impacts the removal efficiency of COD and the substrate.

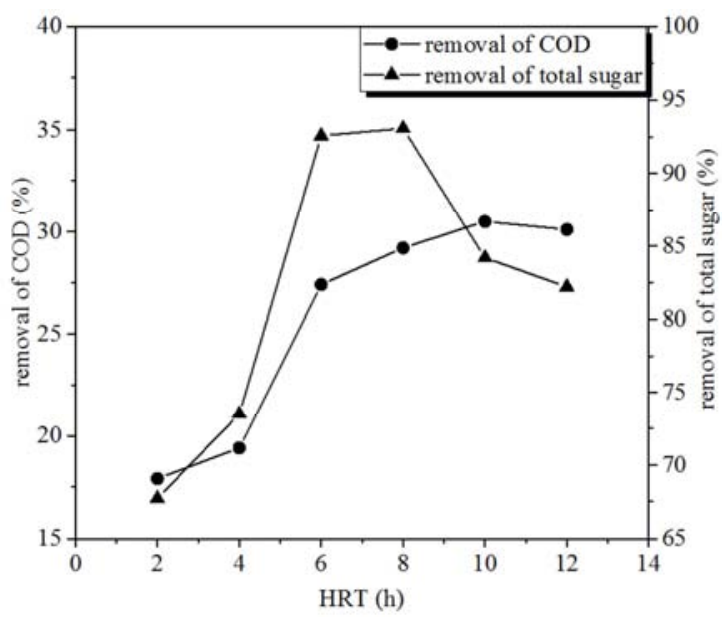

Figure 13. Removal of COD and total sugar in the CSTR system during fermentation at different HRT.

HRT not only has impact on metabolic characteristics of microbial community and the internal environmental conditions of the CSTR, but also has obvious impact on biomass of the system and biological activity.

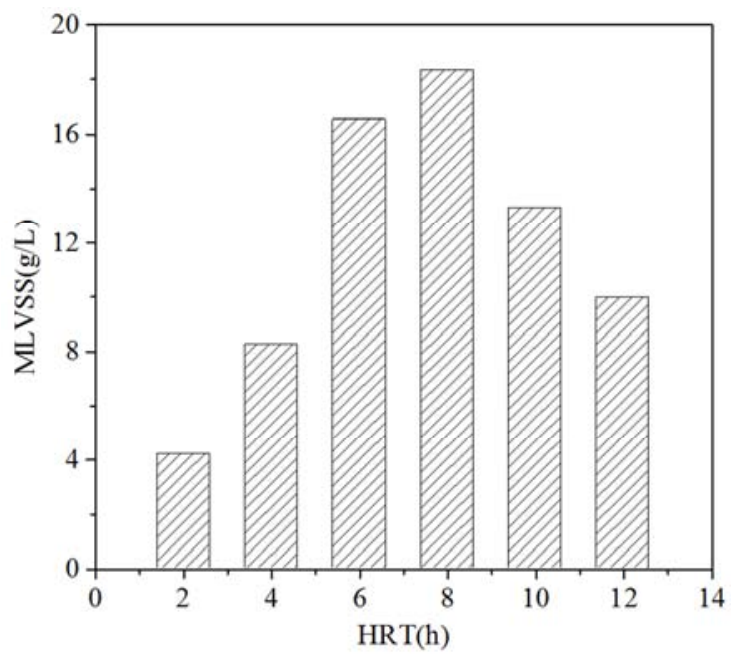

Figure 14. Biomass in the CSTR system at different HRT.
Figure 14 showed effect of HRT on the microbial biomass. It is shown that the HRT increased from $2 \mathrm{~h}$ to $8 \mathrm{~h}$, and MLVSS appeared obvious increasing from $4.19 \mathrm{~g} \cdot \mathrm{L}^{-1}$ to $18.35 \mathrm{~g} \cdot \mathrm{L}^{-1}$. Anaerobic activated sludge has been "flushed" strongly under $2 \mathrm{~h}$ HRT, and the biomass concentration of the CSTR was very low because part of the micro-organisms of less flocculation or in the suspension state has lost due to the effect of "flushing". When the bioreactor reached stable state under these conditions, the biomass kept at $4.19 \mathrm{~g} \cdot \mathrm{L}^{-1}$. When HRT reached $6 \mathrm{~h}$, the biomass has been stable at $16.54 \mathrm{~g} \cdot \mathrm{L}^{-1}$, at the time, the amount of hydrogen in the reaction system of anaerobic sludge can reach $9.4 \mathrm{~L} \cdot \mathrm{d}^{-1}$. And the amount of the biomass reaching its highest $18.35 \mathrm{~g} \cdot \mathrm{L}^{-1}$ when the HRT was $8 \mathrm{~h}$, hydrogen production rate got the highest around $9.8 \mathrm{~L} \cdot \mathrm{d}^{-1}$.

\subsubsection{Influence of OLR for Fermentation}

The Organic Load Rate (OLR) plays great important on the efficiency of the reactor. As shown in figure 15, the $\mathrm{H}_{2}$ production initially increased with an increase in OLR and the OLR tested $\left(24 \mathrm{kgCOD} \cdot \mathrm{m}^{-3} \cdot \mathrm{d}^{-1}\right)$ gave the highest $\mathrm{H}_{2}$ production of $13.2 \mathrm{~L} \cdot \mathrm{d}^{-1}$. When the OLR was a little bit low, the organic can only support the living and breeding of the microorganism, and none other organic was changed into hydrogen energy. So the hydrogen production initially increased. While the OLR exceed $24 \mathrm{kgCOD} \cdot \mathrm{m}^{-3} \cdot \mathrm{d}^{-1}$, the hydrogen production didn't increase along with the increasing of OLR, it dropped sharply instead. This was because that the volatile fatty acids produced during the fermentation accumulated greatly, which lead to sharp decline in $\mathrm{pH}$ of the reactor, under which circumstances the microorganism activity was inhibited and the hydrogen production declined.

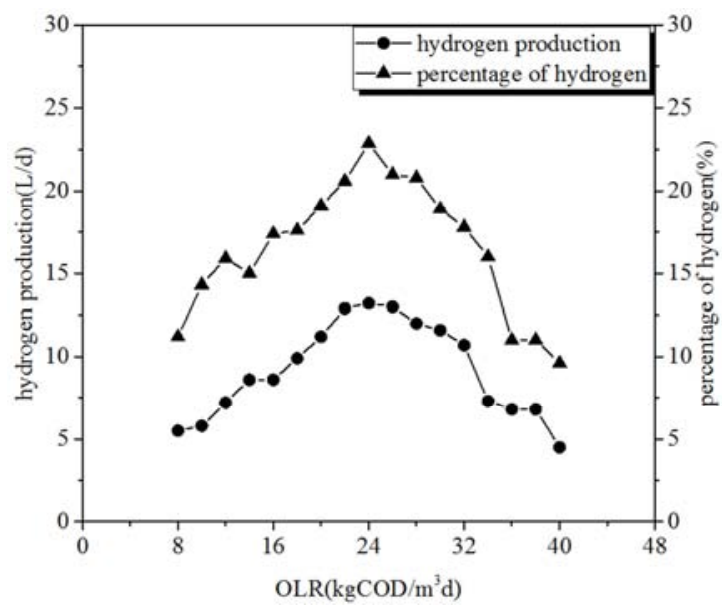

Figure 15. Hydrogen production under different OLRs.

Figure 16 showed us the effect of OLR on $\mathrm{pH}$ during the fermentation. When the influent $\mathrm{pH}$ kept around 7.00, the effluent $\mathrm{pH}$ changed under different OLRs. When OLR increased from $8 \mathrm{kgCOD} \cdot \mathrm{m}^{-3} \cdot \mathrm{d}^{-1}$ to $24 \mathrm{kgCOD} \cdot \mathrm{m}^{-3} \cdot \mathrm{d}^{-1}$, the effluent $\mathrm{pH}$ kept relatively stable around $4.50 \sim 5.00$, while OLR exceed $24 \mathrm{kgCOD} \cdot \mathrm{m}^{-3} \cdot \mathrm{d}^{-1}$, the effluent $\mathrm{pH}$ greatly dropped under 4.00 because of the accumulation of the volatile fatty acids produced. The low $\mathrm{pH}$ greatly harmed the stability of the operation of the CSTR system. And the hydrogen production efficiency was affected. So reasonable OLR are 
needed to keep the operation of the reactor, and the optimal OLR in this essay was $24 \mathrm{kgCOD} \cdot \mathrm{m}^{-3} \cdot \mathrm{d}^{-1}$, where the highest hydrogen production was got at $13.2 \mathrm{~L} \cdot \mathrm{d}^{-1}$.

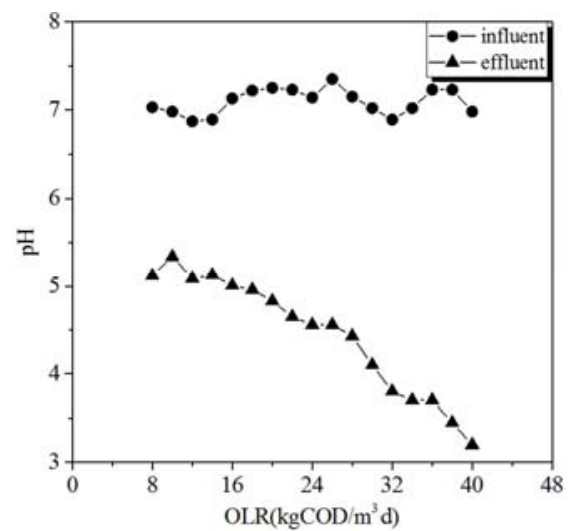

Figure 16. $p H$ of influent and effluent under different OLRs.

\section{Conclusion}

Yeast production wastewater can work as the substrate of the biohydrogen production. In this essay, MF-CSTR process was used to pre-treat yeast production wastewater, where the concentrate after filtration got to be resources recycled and the effluent was put into CSTR for biohydrogen production. The yeast wastewater got removal efficiency of SS and Chroma around $95 \%$ and $88 \%$ with the aeration rate $0.15 \mathrm{~m}^{3} \cdot \mathrm{h}^{-1}$. 10 days worked as a period to clean the membrane and recycle the concentrate, and 1.09yuan economic benefit could be got by dealing with 1t water. By comparing the hydrogen production efficiency of wastewater before and after filtration, result showed that filtration could do good to the fermentation efficiency. The startup of the CSTR system got successful at about 15 days, when the removal efficiency kept about $27 \%$ and the $\mathrm{pH}$ of the system kept stable at about 4.5 And based on the experimental results obtained, it can be concluded that the HRT and OLR appeared to be significant parameters for the operation of CSTR system. When the HRT was $8 \mathrm{~h}$, and the OLR $24 \mathrm{kgCOD} \cdot \mathrm{m}^{-3} \cdot \mathrm{d}^{-1}$, CSTR system got the highest hydrogen production $\left(13.2 \mathrm{~L} \cdot \mathrm{d}^{-1}\right)$. The study indicated that yeast industry wastewater would not only provide the energy source but also solve the waste treatment problems under MF-CSTR process. Therefore, dual benefits were obtained from fermentation of yeast industry wastewater, thereby making the process more economical and valuable.

\section{Acknowledgements}

This research was supported by National Nature Science Foundation of China, Development Program of China (863 Program) (Grant no.2011AA060905).

\section{References}

[1] Hosseini SE, Andwari AM, Wahid MA, et al. A review on green energy potential in Iran. vol 27, Renew Sustain Energy Rev, 2013, pp 533-45.
[2] Hosseini SE, Wahid MA, Aghili N. The scenario of greenhouse gases reduction in Malaysia. Vol 28, Renew Sustain Energy Rev, 2013, pp 400-9.

[3] Periyasamy S. Biswarup S, Chiu-Yue, L. High-rate fermentative hydrogen production from beverage wastewater. vol 14, 2015, pp 1-9.

[4] Kapdan IK, Kargi F. Bio-hydrogen production from waste materials. vol 38, Enzyme Microb Technol, 2006, pp 569-82.

[5] Periyasamy S, Gopalakrishnan K, et al. Feasibility of enriched mixed cultures obtained by repeated batch transfer in continuous hydrogen fermentation. vol 41, International Journal of Hydrogen energy, 2006, pp 4393-4403.

[6] Karadag D, Koroglu OE, Ozkaya B, Cakmakci M, Heaven S, Banks C. A review on fermentative hydrogen production from dairy industry wastewater. vol 89 , J Chem Technol Biotechnol, 2014;pp 1627-36.

[7] Lin CY, Lay CH, Sen B, Chu CY, Kumar G, Chen CC, et al. Fermentative hydrogen production from wastewaters: a review and prognosis. vol 37, Int J Hydrogen Energy, 2012, pp 15632-42.

[8] Mustafa E, Recep K, Hale O. Source Based Characterization and Pollution Profile of a Baker's Yeast Industry [J]. vol 39, Clean Soil, Air, Water: A Journal of Sustainability and Environmental Safety, 2011, pp. 543-548.

[9] Z. Lianga, Y. Wang, Y. Zhou, H. Liu, Coagulation removal of melanoidins from biologically treated molasses wastewater using ferric chloride. vol 152, Chem. Eng. J. 2009, pp:88-94.

[10] M. Kobya, S. Delipinar, Treatment of the baker's yeast wastewater by electrocoagulation. vol 154, J. Hazard. Mater. 2008, pp 1133-1140.

[11] Saareleht M, Vaarmets E, Menert T: Liquid and gas chromatographic studies of the anaerobic degradation of baker's yeast wastewater. Vol 3, Procedia Chem 2010, pp. 120-129.

[12] Marcucci M, Nosenzo G, Capannelli G. Treatment and reuse of textile effluents based on new ultrafiltration and other membrane technologies. Vol 138, Desalination, 2001, pp.75-82.

[13] S.H. Mutlu, U. Yetis, T. Gurkan, L. Yilmaz, Decolorization of wastewater of a baker's yeast plant by membrane processes, vol 54, Water Res. 2002, pp 609-616.

[14] M. Liu, H. Zhu, B. Dong, Y. Zheng, S. Yu, C. Gao, Submerged nanofiltration of biologically treated molasses fermentation wastewater for the removal of melanoidins, vol 223, Chem. Eng. J. 2013, pp 388-394.

[15] A. Rahimpour, M. Jahanshahi, M. Peyravi, Development of pilot scale nanofiltration system for yeast industry wastewater treatment, vol 12 J. Environ. Health Sci. Eng. 2014, pp 1-7.

[16] American Public Health Association, AWWA, Water Environment Federation. Standard methods for the examination of water and wastewater. 20th ed. Washington, D. C., USA: APHA, AWWA, and WEF; 1998.

[17] Show KY, Lee DJ, Chang JS. Bioreactor and process design for biohydrogen production. vol 102, Bioresour Technol 2011, pp 8524-33.

[18] G. F. Zhu, J. Z. Li, P. Wu, H. Z. Jin, Z. Wang, The performance and phase separated characteristics of an anaerobic baffled reactor treating soybean protein processing wastewater. Vol 99, Bioresource Technology, pp. 8027-8033. 